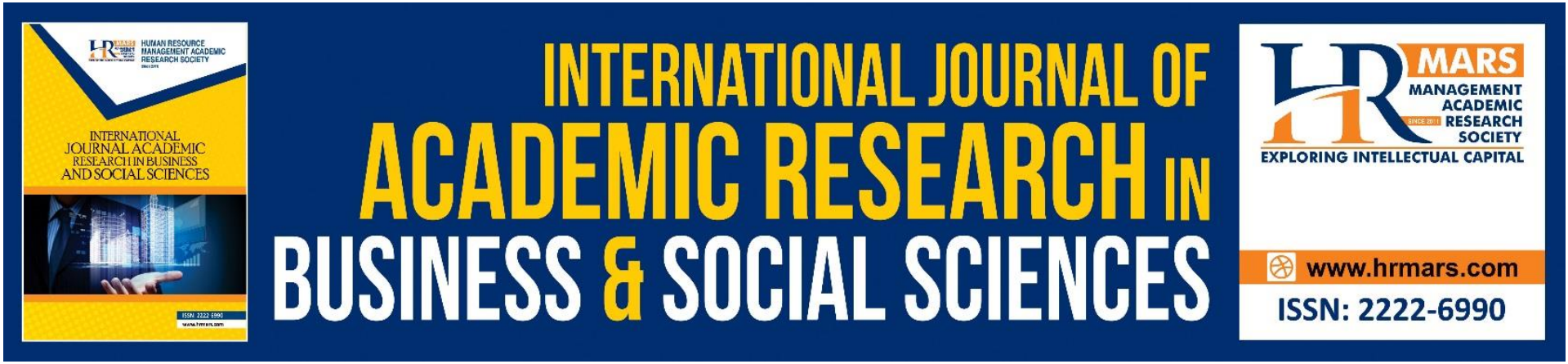

\title{
An Investigation of Motives and Fear of Learning Japanese As a Foreign Language
}

Nur Anisah Tan Abdullah, Sarinah Sharif, Choong Pow Yean, Noor Hanim Rahmat, Nor Rasimah Abdul Rashid, Normah Ahmad

To Link this Article: http://dx.doi.org/10.6007/IJARBSS/v12-i1/12150

DOI:10.6007/IJARBSS/v12-i1/12150

Received: 11 November 2021, Revised: 15 December 2021, Accepted: 01 January 2022

Published Online: 26 January 2022

In-Text Citation: (Abdullah et al., 2022)

To Cite this Article: Abdullah, N. A. T., Sharif, S., Yean, C. P., Rahmat, N. H., Rashid, N. R. A., \& Ahmad, N. (2022). An Investigation of Motives and Fear of Learning Japanese As a Foreign Language. International Journal of Academic Research in Business and Social Sciences, 12(1), 2209-2229.

Copyright: @ 2022 The Author(s)

Published by Human Resource Management Academic Research Society (www.hrmars.com)

This article is published under the Creative Commons Attribution (CC BY 4.0) license. Anyone may reproduce, distribute, translate and create derivative works of this article (for both commercial and non0-commercial purposes), subject to full attribution to the original publication and authors. The full terms of this license may be seen at: http://creativecommons.org/licences/by/4.0/legalcode

Vol. 12, No. 1, 2022, Pg. 2209- 2229

Full Terms \& Conditions of access and use can be found at http://hrmars.com/index.php/pages/detail/publication-ethics 


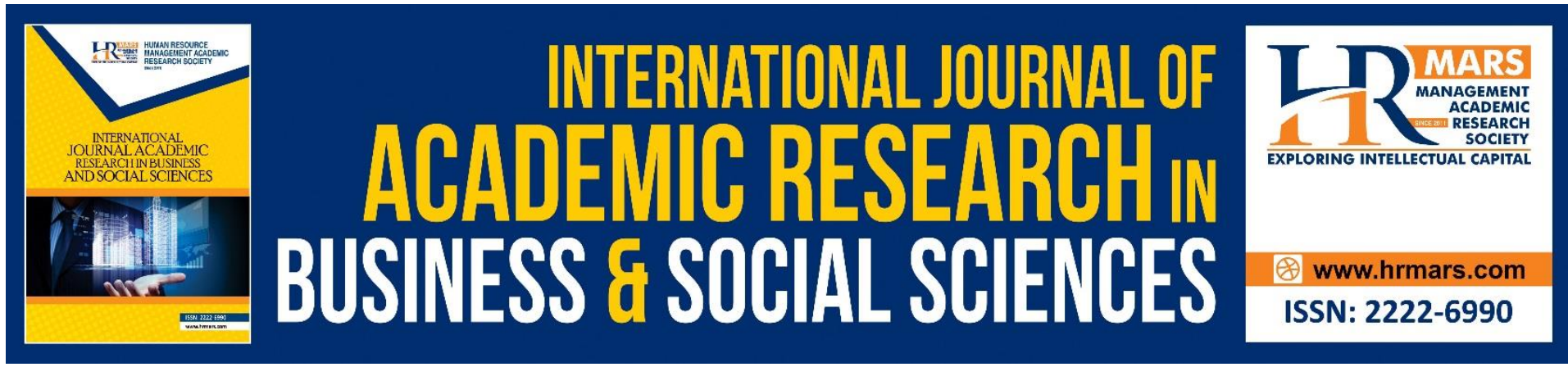

\title{
An Investigation of Motives and Fear of Learning Japanese As a Foreign Language
}

\author{
${ }^{1}$ Nur Anisah Tan Abdullah, ${ }^{2}$ Sarinah Sharif, ${ }^{3}$ Choong Pow \\ Yean, ${ }^{4}$ Noor Hanim Rahmat, ${ }^{5}$ Nor Rasimah Abdul Rashid, \\ ${ }^{6}$ Normah Ahmad \\ 1,2,3,5 \& 6 Akademi Pengajian Bahasa Universiti Teknologi MARA Cawangan Shah Alam, \\ ${ }^{4}$ Akademi Pengajian Bahasa Universiti Teknologi MARA Cawangan Johor Kampus Pasir \\ Gudang \\ Email: anistan@uitm.edu.my, sarinah@uitm.edu.my,choon322@uitm.edu.my, \\ noorh763@uitm.edu.my,nor_rashimah@uitm.edu.my,normah698@uitm.edu.my
}

Abstract

Research showed that learners faced negative and positive factors in learning a foreign language. The negativities may be the barrier for the students to succeed in the learning process. This research examines what makes the students stay in lectures and what elements could cause the students to quit. This research aims to investigate the motives/motivations that students encounter and whether these positive elements help the students overcome the fear and anxiety they face. This research adopted the quantitative approach. A survey is used as the instrument. A questionnaire with five sections on demography profile, motivation to learn, communication and apprehension, fear of negative evaluation, test anxiety was questioned by the students. Two hundred and twenty-one students from three disciplines in a public university in Malaysia participated in the questionnaire. The result shows that students do experience fear and anxiety during lectures. However, the desire to learn makes the students put in some effort to overcome the negative factors. When the desire to learn and the efforts are implemented in learning the Japanese language, students gradually feel comfortable and at ease when attending lectures. This research indicated that fun and interactive activities and an enjoyable lesson should be planned to assist students to overcome the negatives and succeed in mastering the language.

Keywords: Motives, Fear, Japanese Language, Foreign Language

\section{Introduction}

Background of Study

The speed of the globalisation process has forced many to learn foreign languages (Remírez, 2014). Schools, Colleges have begun to introduce foreign language courses. In the excitement of teaching such courses, educators and researchers have been conducting studies so that the curriculum and syllabus are on the right track and meet the market's needs (Supida, 2020). Apart from that, the issue of teaching and learning also needs to be given attention so that teachers and students alike can obtain optimal returns. 
Language is part of the culture of a society. The richness and wonderfulness of Japanese culture made the language one of the most famous foreign languages learned in the world. The Japan Foundation Annual Report 2019-2020, referring to the report on Japanese language education abroad 2018, for the past 39 years, ie. from the year 1979 to 2018, Japanese language learners have increased to more than 30 times $(127,167$ to $3,851,774)$, teachers involved in the teaching of the language too have increased almost 19 times $(4,097$ to 77,323$)$, and Japanese language institutions increased 16.3 times $(1,145$ to 18,661$)$. This remarkable development was not surprising as many world communities engaged with Japanese animation, gaming, food, fashion, and others. Li (2014), in her research, mentioned that learners of the Japanese language should master not only the language but also fosters awareness of Japanese culture itself. In this way, students can communicate well with the language they learn.

The development of Japanese language education in Malaysia has also grown rapidly and very encouragingly. Students at the secondary school level show great interest in learning the language. Japan Foundation Report in 2017 stated that 33,224 students in Malaysia are learners of the language, 430 Japanese language teachers, and 176 institutions offering Japanese language education.

With the encouraging growth of the learning and teaching of the Japanese Language in Malaysia, researchers have begun to investigate various aspects of the teaching and learning of the language. The study done by Boon et al (2021) shows that negative factors in foreign language learning causing fear to students can sometimes be overcome by positive factors that cause students to continue their studies. Results from the survey done by Singh et al (2021) show that students in a public university are very motivated when learning the Japanese language as a foreign language. The motivations of these students are very much influenced by the teachers and courses offered.

In this research, the researchers are studying the motives or motivations and fear of learners in one of the public universities while learning Japanese as a foreign language.

\section{Statement of Problem}

Motivation has been recognised as one of the most important aspects impacting foreign-language learning (Gardner, 1985), yet it is more complicated than most people believe. Gardner defines "motivation" as a mix of effort, a desire to attain the aim of learning the language, and a positive attitude toward learning the language, according to his socialeducational model. Singh (2021) research has found that integrative and attitudinal motivational orientation were important elements in learning Japanese as a foreign language among students at a Malaysian public institution. The students were highly motivated in knowing Japanese culture and society, enjoyed Japanese comics, music, movies, films, and TV drama series gained a greater knowledge and appreciation of the Japanese way of life, and satisfying personal interests in terms of integrative motivation. Meanwhile, students are very motivated to study Japanese for instrumental motivation reasons. It will assist them in obtaining a decent career, meeting academic requirements, being informed, traveling, and feeling proud of their ability to speak the target language. Nuibe (1995) recommended the categorization of Extrinsic Motivation as Instrumental, Integrative, and Provocative Motivation. Intrinsic motivation is defined as "interest and curiosity," which refers to a desire to learn about Japanese people and the Japanese language, as well as "identification with the model," which refers to the desire to imitate a teacher who speaks Japanese fluently, and 
"interaction with peers," which refers to the desire to communicate with Japanese people using Japanese.

However, learning a foreign language with many distinct linguistic elements from one's home language will provide learners with unique problems. The students will be entering unfamiliar territory, which leads to anxiety. Purwaningrum (2020) found that students were very concerned about speech anxiety and the fear of poor assessment. Because the chance to speak Japanese outside of the classroom was limited, students were concerned about the prospect of communication issues. Furthermore, students were nervous about receiving unfavourable feedback from others for fear of losing face, which is a common occurrence among Indonesian undergraduate students. As a result, the students were very worried about what others thought of them and were fearful of criticism and negative feedback. Teachers and instructors must play a crucial role in ensuring that pupils are not afraid of being assessed. As Dörnyei (2005) points out, by being taught a range of learning methodologies, students may gain confidence in their capacity to learn. It's also been argued that training communication methods might help with communication problems.

Hence, this study is done to investigate the motives and fear of learning Japanese as a foreign language. This investigation is done to answer the following questions;

- How does desire influence the learning of Japanese as a foreign language?

- How does effort influence the learning of Japanese as a foreign language?

- How does fear influence the learning of Japanese as a foreign language?

- How do positive affects influence the learning of Japanese as a foreign language?

\section{Literature Review}

Motivation in Learning

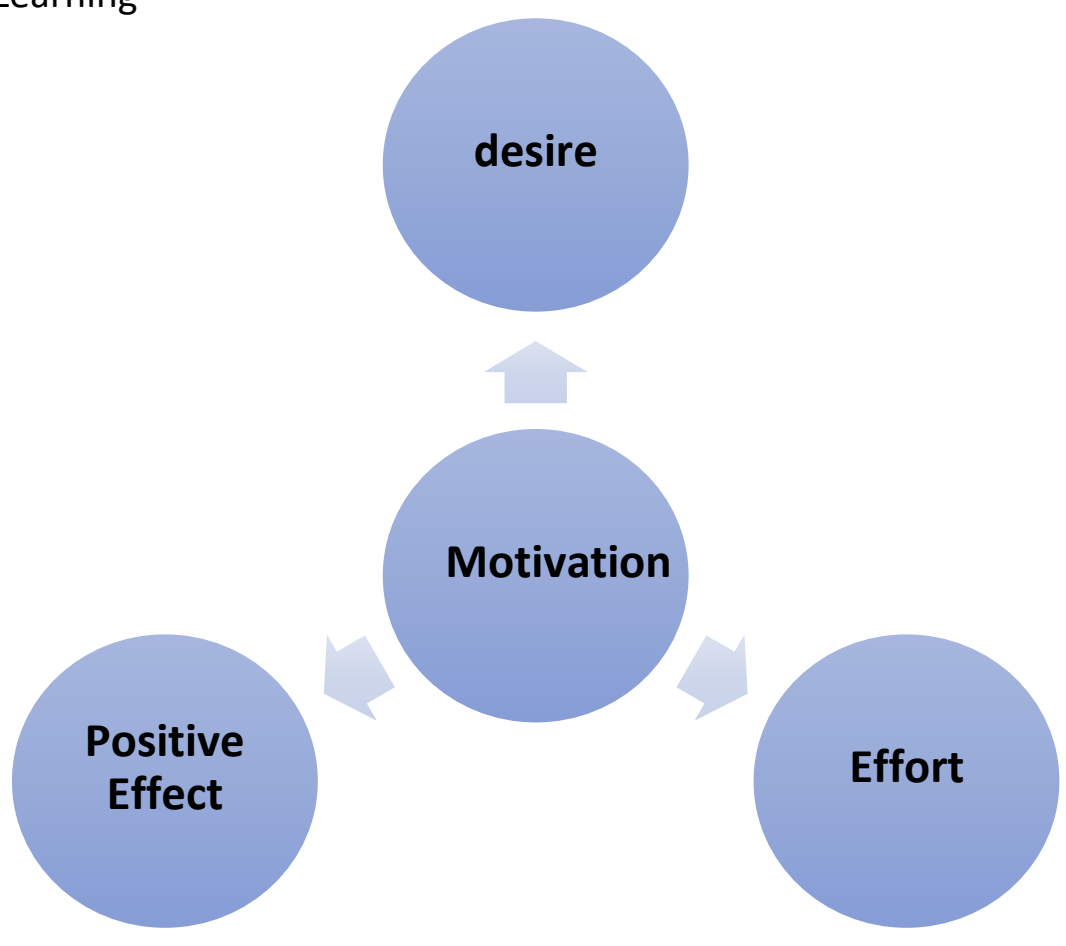

Figure 1: Motivation (source: Gardner, 2001) 
Figure 1 presents motivation theory in learning languages by (Gardner, 2001). Gardner (2001) revealed that motivation includes three main elements. Firstly, a person will be motivated to learn if he/she has the (a) desire to learn. This desire will determine the type of/ how much effort the person puts into the learning. The two combined can then lead to (c) positive effects felt by the learner. This affect can be seen by the way the learner enjoys the task related to learning.

Motivation in Learning Foreign Languages

Motivation research was led by Gardner's Motivation Theory based on Gardner's Motivation model (1985) for the past decades. There are integrative motivations that consist of integrative orientation such as interest in the people and culture of that target language group and instrumental motivation which relates to the purposes of learning the language. Learners who hope to get a better job or higher salary are considered instrumental motivations (Gardner, 1985).

Integrative motivations made learners learn well which was revealed by the past research. However, Dornyei (1990) has a query about the relevance in foreign language learning situations where learners have no chance to interact with the community. Dornyei has investigated the components of motivation in foreign-language learning which involve students who were learning the target language in an institution. The respondents were not regularly interacting with the target language community. According to Dornyei (1990), a motivational construct was assumed consisting of Instrumental Motivational Subsystem, Integrative Motivational Subsystem, Need for Achievement and Attributions about Past Failures. Dornyei (1990) also found that the Instrumental Motivational Subsystem and Need for Achievement are very important for learners to master an intermediate target language proficiency.

\section{Fear of Learning Foreign Languages}

Research is done by Lin (2015) also indicated anxiety in the beginners level among students who are majoring in the Japanese language during their learning process. $54 \%$ of the male students have high language learning anxiety. According to the researcher, students experience language anxiety in terms of communicating and the anxiety heightens when students communicate with native Japanese speakers. Likewise, research was done by Awuah (2018) among Czech students who learned English as a foreign language and experienced students who shy away from imparting their ideas in class when the lesson required them to participate. According to the researcher, this is due to the students' hesitance to speak due to fear of making grammatical errors while communicating in English. While Vetrinskaya et.al (2020) listed out some of the fears students often faced were negative motivations, punishments, and fear of not communicating effectively compared to other students. She stated the most important emotional component of the learning process was students need to feel successful while studying. Lectures can help to overcome this fear by giving clear instructions and encouraging teamwork among students.

\section{How Japanese is Learnt}

Japanese is an orthographic language where the writing system uniquely consists of two qualitatively different scripts: orthographic kanji, derived from Chinese characters, and two forms of syllabic hiragana and katakana (Ijuin \& Wydell, 2017). Due to the complex writing 
system and a complicated hierarchy of politeness, the Japanese language is considered one of the most difficult to learn by nonnative learners. How Japanese is learnt depends on the goals because learning strategies are generally deliberate and goal oriented.

According to Chamot (2005), learning strategies are procedures that facilitate a learning task. Meanwhile, Oxford (1990) defined language learning strategies as "specific actions taken by the learner to make learning easier, faster, more enjoyable, more selfdirected, more effective, and more transferable to new situations." Oxford suggested that language learning strategies are divided into two categories; direct and indirect strategies. Direct strategies include memory strategies, cognitive strategies, and compensation strategies. On the other hand, indirect strategies consist of metacognitive strategies, affective strategies, and social strategies. Gonzales (1997) conducted a study on learners of the Japanese language in the Philippines. The results showed that Filipino learners chose to employ more indirect strategies than direct strategies, and social strategies were employed more than other strategies.

Tamada (1996) investigated the relationship between learners' personal factors and their choices of language learning strategies. It was found that learners' sex, integrative, and instrumental motivation affected their LLS choices significantly. Zakaria et al (2017) conducted a study on language learning strategies among Japanese language learners in a Japanese Language Proficiency Test (JLPT) preparatory class. The study attempted to find the relationship between language learning strategies and learner autonomy in the context of learning Japanese in Malaysia. The findings showed that students employ the majority of language learning strategies on a regular basis. In terms of learner autonomy, the findings reveal that students recognise and comprehend their responsibility for autonomous learning activities, but they believe they lack the competence to carry out such responsibilities properly. There was also a strong link discovered between language learning strategies and the degree of learner autonomy.

Past Studies

Past Studies in Motivation to Learn Foreign Languages

Researchers did many studies on the learning of a foreign language. There have been many past studies on the motives of foreign language learning. Ramírez's (2014) research objective was to determine the influencing factors of motivation and achievement in foreign language learning and identify several motivational strategies to increase student motivation. This research selected twenty students from the intermediate Trade Course with low motivation in foreign language learning and low competency of the target foreign language. The researcher joined the classes and observed the students' learning process before giving questionnaires to the students. During the observation, the researcher noticed that the main reason the students got demotivated was the teaching methodology applied by the teacher. The teacher tended to use the traditional method and avoid using technology tools.

On the other hand, students were not motivated as they had no interest in learning a foreign language and did not see the importance of knowing one. After the observation, the researcher distributed two questionnaires to the students. The first one is related to students' initial opinions about the foreign language classes, and the second is their opinions after the researcher participated in the classroom. The researcher analysed the questionnaires and came up with a few interactive activities, such as group work and communicative activities. 
Students had to apply their communicative skills into practice during the interactive activities. They also applied their expertise in using technology. They worked with one another during the activities. This study shows that to increase students' motivation in learning a foreign language, the students need to know the purpose of learning and are interested in learning the language. The implementation of traditional and modern methods applies. These two methods need to be combined depending on the content, lesson objectives, and the target students.

Nowadays, with the development of gadgets, especially smartphones becoming popular, In the study by Lin et al (2017), they investigated the usage of technology tools in the learning process. They became more flexible, with no time restriction and no learning space/place limitation. One hundred sixteen students from 4 classes are selected. Fifty-eight students are the experimental group that proceeded with the digital learning, and another 58 students are the control group where they remained learning using the traditional method. All 116 students are tested and asked to answer a questionnaire. Lin et al. found that 1 . Digital learning reveals better positive effects on learning motivation and learning outcome than traditional teaching does. 2. Learning motivation obtains positive effects on learning effect and learning gain in learning outcome. In conclusion, digital learning is a suitable learning method for the young generation compared to traditional learning. Through this digital learning, students are more motivated.

Studies show that being demotivated will affect university students' academic achievement in Malaysia. For this reason, Azar \& Tanggaraju (2020) researched this matter. The study investigated the type and level of motivation of Bachelor students in learning English in one of the private universities in Malaysia. This study uses a quantitative method in which data are collected through a questionnaire adapted from Gardner's (1972) Attitude, Motivation Test Battery (AMTB). One hundred fifty students answered the questionnaire, and the data were analysed quantitatively. The findings indicate that the students had a higher instrumental motivation for learning English compared to integrative, resultative, and intrinsic motivation. However, all four types of motivation are at a high level of motivation.

\section{Past Studies in Fear of Foreign Language Learning}

Language anxiety, according to Horwitz (1986), is "a discrete complex of selfperception, attitudes, emotions, and behaviours associated with classroom language acquisition that arises from the distinctiveness of the language learning process" (p. 128). Much research has been conducted to look at the anxiety associated with learning a foreign language. The Rahmat (2020) study contributes to the cycle of fear in foreign language learning. Horwitz (1986), who established the Foreign Language Classroom Anxiety Scale, was employed in this research. The demographic profile included seven items, eight items for communication anxiety, and five items for exam anxiety. There were additional nine answers about being afraid of poor evaluations and language lessons. The findings show that students' communication anxiety may snowball into learners' worry of failing the exam and receiving a poor grade. This fear may then spread to foreign language classes.

Hashemi (2011), on the other hand, looked at the causes of language anxiety among Iranian language learners in the classroom and in the social setting and proposed a number of ways for dealing with it. A qualitative semi-structured interview and focus-group discussion approach were utilised in this study as the research instrument. The results obtained from this study suggested that language anxiety can be caused by learners' sense of self, selfrelated cognitions, language learning difficulties, differences in learners' and target language 
cultures, differences in the social status of speakers and interlocutors, and the fear of losing self-identity.

Past Studies in difficulties in Learning Japanese

Many studies have been done to investigate the motives which are related to the difficulties of learning foreign languages (e.g. Taguchi, Magid, \& Papi, 2009; Mardani, D., 2019; Yashima, Nishida \& Mizumoto, 2017).

Santiar et al (2018) have conducted research to identify students' difficulties in comprehending complex sentences at a university outside Japan. 34 of the respondents who were majoring in Japanese for two years were asked to explain what they understood from the two most difficult sentences selected from a passage without referring to the dictionary. The findings indicated that grammatical morpheme and clause order were difficulties for most of the students.

Rethinasamy et al (2021) have surveyed undergraduates' beliefs and motivation for learning Japanese as a foreign language. 150 undergraduates in one of the universities in Malaysia have participated in the investigation via questionnaires. The study also revealed that it is more difficult for students to obtain listening and speaking skills compared to reading and writing skills.

\section{Conceptual Framework}

This study is rooted in Gardner's motivation for learning languages and also Horwitz, Horwitz and Cope (1986) fear of foreign language learning. To begin with, learners embark on foreign language courses from their initial desire to learn the language. This desire determines the kind of effort (or how much effort) the learner puts into learning the chosen foreign language.

However, the learning environment can escalate or decrease the fear of learning a foreign language. This fear could be comprehension apprehension, fear of negative evaluation, or even fear of test anxiety. When the fear of learning the language is overcome (or not), then the learners can end up either having or losing the positive effect towards learning the foreign language.

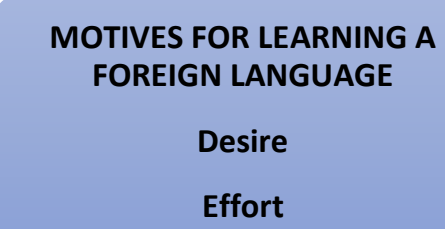

Figure 2- Conceptual Framework of the Study- Motives and Fear of Learning Japanese 


\section{Methodology}

This quantitative research is done to investigate learners' motives and fear of learning Japanese. The instrument used is a survey adapted from Gardner (2001) and Horwitz, Horwitz and Cope (1986). 221 respondents were purposively chosen to answer the survey. The survey has 3 main sections. With reference to Table 1 , section $A$ has items on the demographic profile. Section B has 17 items on Motivation and section C has 33 items on the Fear of learning Foreign Languages.

Table 1- Distribution of items in the instrument

\begin{tabular}{|c|c|c|c|}
\hline MAIN CONSTRUCT & SECT & CONSTRUCT USED TO MEASURE & $\begin{array}{l}\text { No of } \\
\text { Items }\end{array}$ \\
\hline \multirow{4}{*}{$\begin{array}{l}\text { MOTIVATION } \\
\text { (Gardner, 2001) }\end{array}$} & \multirow[t]{4}{*}{ B } & Effort & 6 \\
\hline & & Desire & 6 \\
\hline & & Positive Effect & 5 \\
\hline & & & 17 \\
\hline \multirow{5}{*}{$\begin{array}{l}\text { FEAR OF LEARNING FOREIGN } \\
\text { LANGUAGES (Horwitz, Horwitz } \\
\text { and Cope, 1986) }\end{array}$} & $\mathrm{C}$ & COMMUNICATION APPREHENSION & 11 \\
\hline & $\mathrm{D}$ & FEAR OF NEGATIVE EVALUATION & 7 \\
\hline & $E$ & TEST ANXIETY & 15 \\
\hline & & & 33 \\
\hline & & TOTAL NO OF ITEMS IN THE SURVEY & 50 \\
\hline
\end{tabular}

Table 2- Reliability Statistics of Survey

\section{Reliability Statistics

\begin{tabular}{c|r}
$\begin{array}{c}\text { Cronbach's } \\
\text { Alpha }\end{array}$ & N of Items \\
\hline .870 & 50 \\
\hline
\end{tabular}

Table 2 presents the reliability statistics for the instrument. SPSS analysis revealed a Cronbach alpha of .870 thus showing a high internal reliability of the instrument used. Data is collected online via goggle form. Data is then analysed using SPSS version 26. Analysed data is presented in the form of percentages and mean scores to answer the 2 research questions 


\section{Findings}

Findings for Demographic Profile

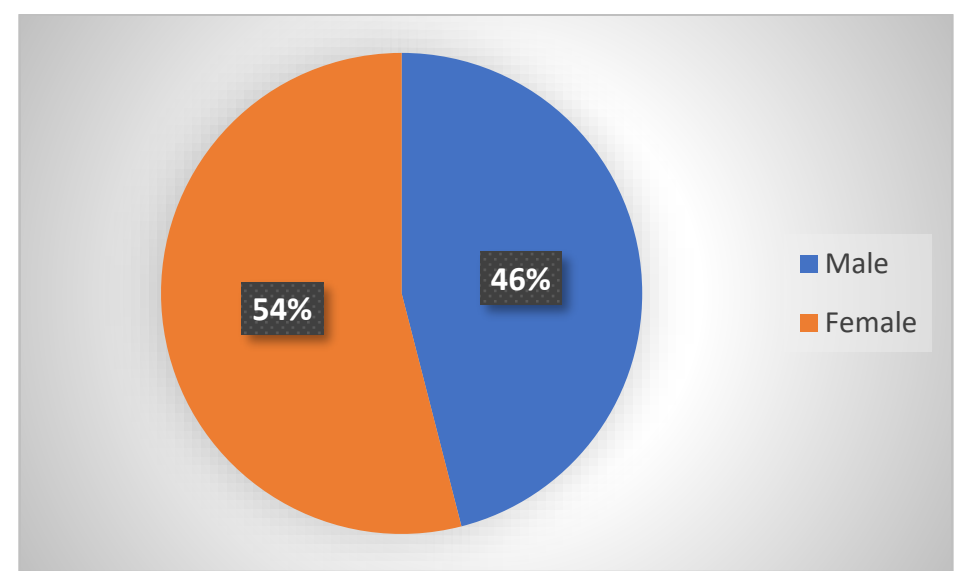

Figure 3- Percentage for Gender

Based on Figure 3 , the analysis on gender shows $54 \%$ of the respondents were female and $46 \%$ were male.

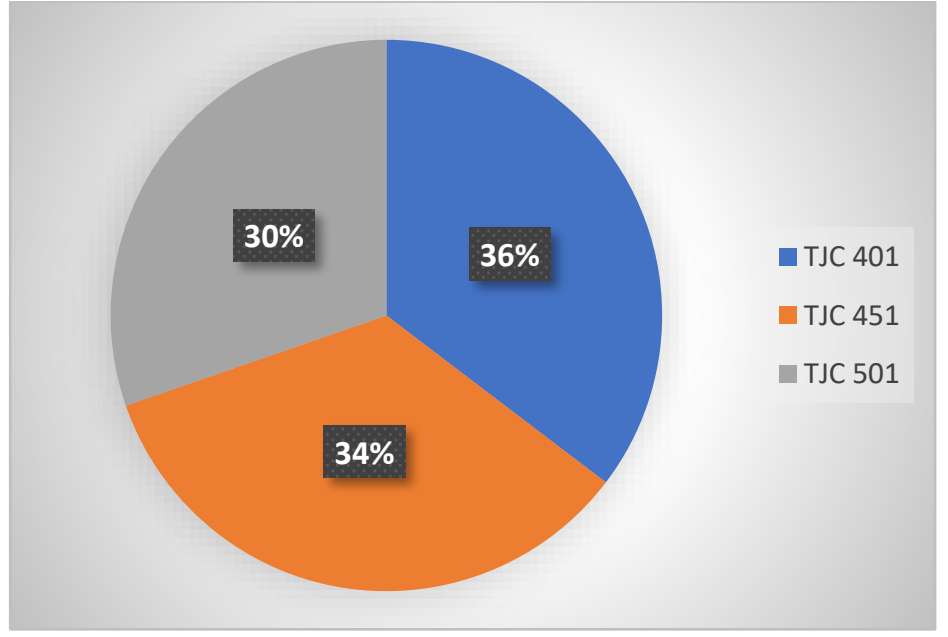

Figure 4-Percentage for Level

Figure 4 , shows the distribution by the level of the Japanese language. $35 \%$ shows that respondents were from level 1 (TJC 401). While 34\% were from level 2(TJC 451). While 30\% of the students were level 3(TJC 501). 


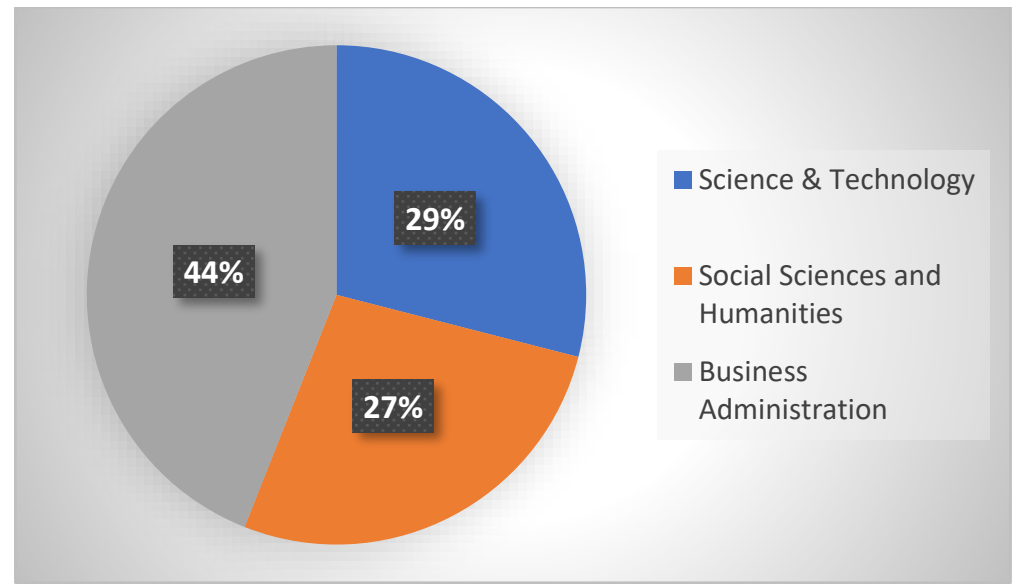

Figure 5- percentage for Cluster

Figure 5 , shows the distribution by cluster. $44 \%$ shows that respondents were from Business Administration. While 29\% were from Science and Technology discipline and $27 \%$ were from Social Sciences and Humanities.

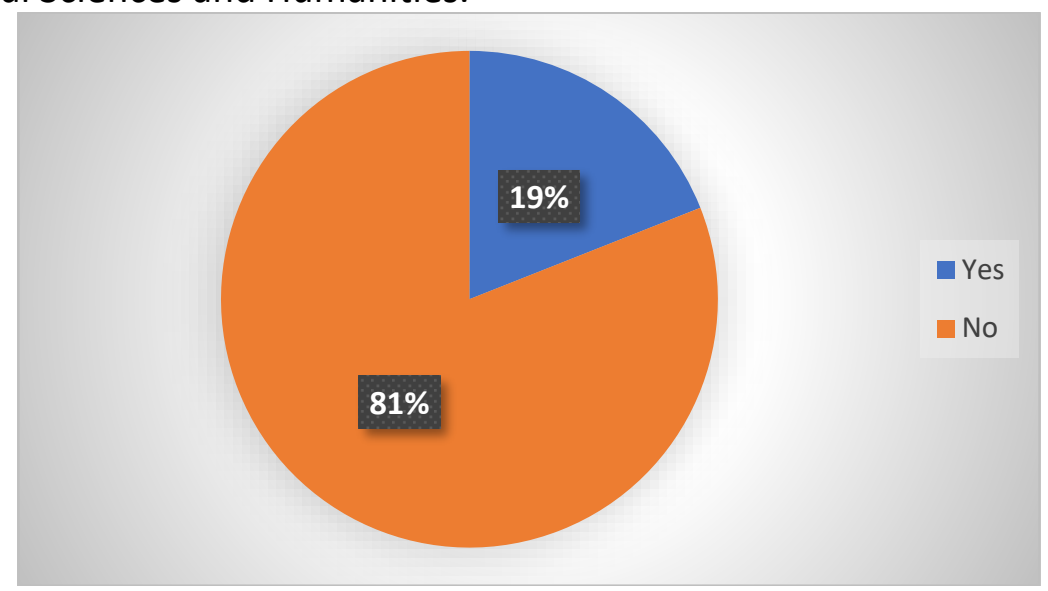

Figure 6- Percentage for History of learning Japanese

Figure 6, shows students ' history of learning Japanese in UiTM. $81 \%$ of the students have no experience learning the language while $19 \%$ have learned the language previously.

Findings for Desire

This section presents data to answer research question No1: How does desire influence the learning of Japanese as a foreign language? 


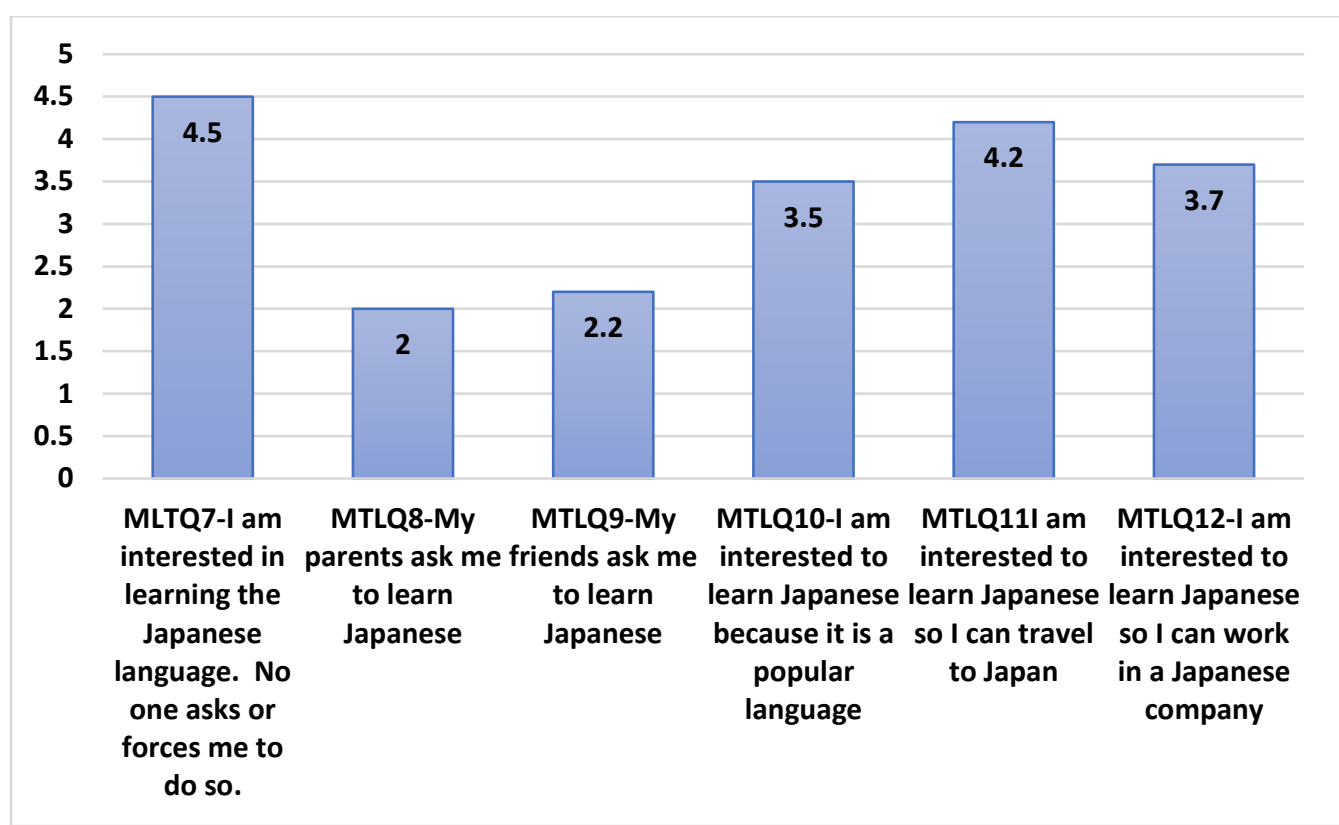

Figure 7-Mean for Desire

Figure 7 above shows that the students have a strong desire to study the Japanese language. This is proven by the highest mean score for desire (4.5) is for "I am interested in learning the Japanese language. No one asks or forces me to do so", followed by (4.2) "I am interested in learning Japanese so I can travel to Japan". Meanwhile, the mean score (3.7) is for "I am interested in learning Japanese so I can work in a Japanese company" and (3.5) is for "I am interested in learning Japanese because it is a popular language". The two lowest mean scores, (2.2) and (2) are for "My friends ask me to learn Japanese" and "My parents ask me to learn Japanese", respectively. This section shows that the students are studying the Japanese language out of their own desire and they are not being forced to take the Japanese language subject.

\section{Findings for Effort}

This section answers research question 2: How does effort influence the learning of Japanese as a foreign language? When learners are motivated to learn a foreign language, they will put in (a) effort. However, their efforts can be affected by their (b) fear of learning the language. 


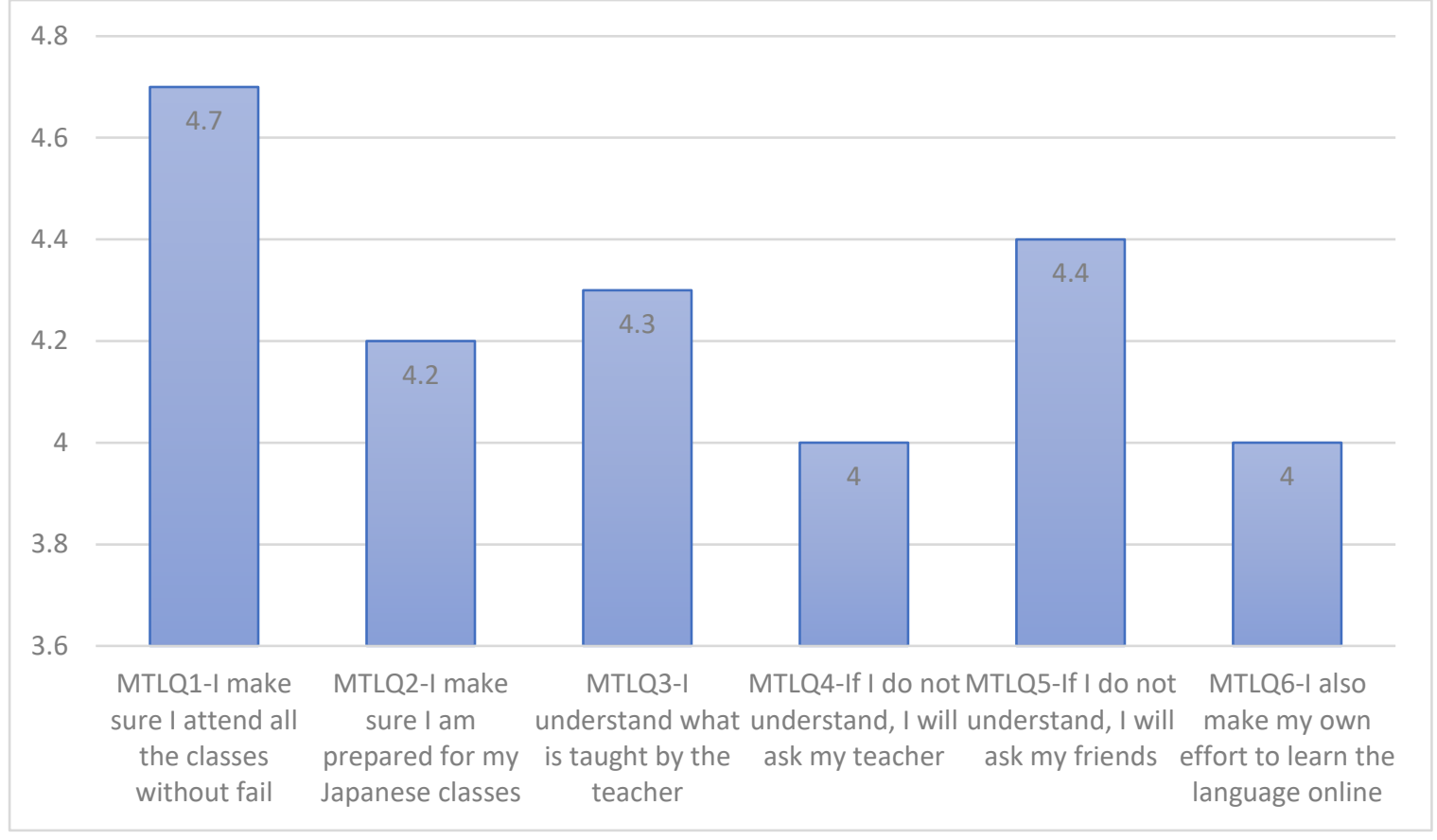

Figure 8a-Mean for Effort

According to the information in Figure 8a, the student has made a significant effort to learn Japanese. "I make sure I attend all of the courses without fail," with a mean score of 4.7, is followed by "If I don't understand, I'll ask my friends," with a mean score of 4.7. (4.4). And "I comprehend what the instructor is teaching" has a mean score of 4.3. Meanwhile, "I comprehend what the instructor teaches" and "I understand what the teacher teaches" have the lowest mean scores (4).

\section{Findings for Fear}

This section presents data to answer research question 3: How does fear influence the learning of Japanese as a foreign language? According to Horwitz, Horwitz and Cope (1986), fear of learning a foreign language can be categorised into three and they are (i) comprehension apprehension, (ii) fear of negative evaluation, and (iii) test anxiety. 


\section{(i) Findings for Communication Anxiety}

CAQ11-I would probably feel comfortable around native speakers of the Japanese language.

CAQ10-I feel overwhelmed by the number of rules I have to learn to speak the Japanese language.

CAQ9-I get nervous when I don't understand every word the language teacher says.

CAQ8-I get nervous and confused when I am speaking in my Japanese language class

CAQ7-I feel very self-conscious about speaking the Japanese language in front of other students.

CAQ6-I feel confident when I speak in Japanese language class.

CAQ5-I get upset when I don't understand what the teacher is correcting.

CAQ4-I would not be nervous speaking the Japanese language with native speakers.

CAQ3-I feel confident when I speak the Japanese language in my Japanese language class.

CAQ2-It frightens me when I do not understand what the teacher is saying in the Japanese language.

CAQI- I never feel quite sure of myself when I am speaking in my Japanese language class.

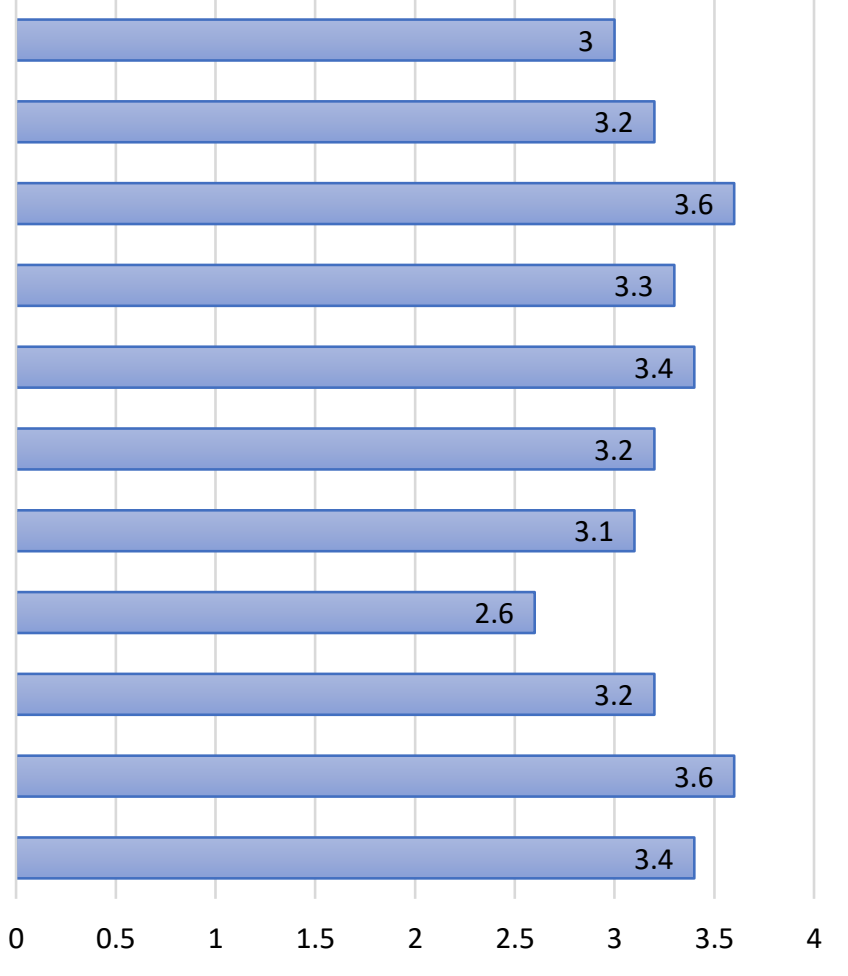

Figure 8b-Mean for Communication Anxiety

Figure $8 \mathrm{~b}$ shows the level of anxiety among students in Japanese language learning. Students feel frightened when they do not understand what the teacher is saying in Japanese (Mean 3.6). The students also have no confidence in speaking (Mean 3.4) and feel nervous when speaking in their Japanese language classes (Mean 3.3). The mean scores for "I would not be nervous speaking the Japanese language with native speakers" are slightly lower (2.6), which shows that students are quite stressed when speaking with native speakers. This might prevent them from performing well in Japanese speaking. 
INTERNATIONAL JOURNAL OF ACADEMIC RESEARCH IN BUSINESS AND SOCIAL SCIENCES

Vol. 12, No. 1, 2022, E-ISSN: 2222-6990 (c) 2022 HRMARS

(ii) Findings for Fear of Negative Evaluation

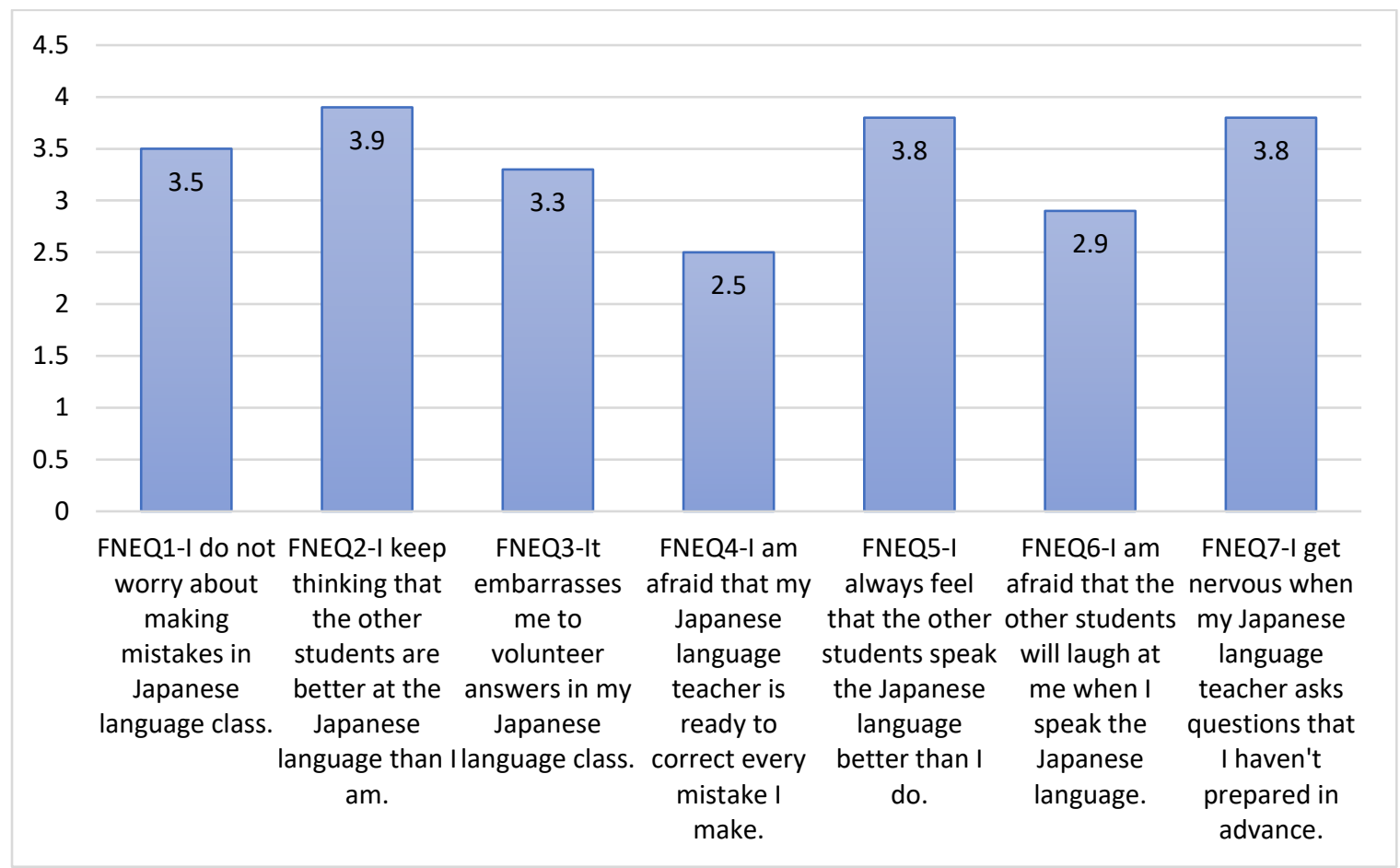

Figure 8c- Mean for Fear of Negative Evaluation

Figure $8 \mathrm{c}$ shows the mean score for fear of negative evaluation. The highest mean score (3.9) was for "I keep thinking that the other students are better at the Japanese language than I am", followed by "I always feel that the other students speak the Japanese language better than I do" and "I get nervous when my Japanese language teacher asks questions which I haven't prepared in advance" with mean score (3.8). The lowest mean score (2.5) was for "I am afraid that my Japanese language teacher is ready to correct every mistake I make". 
(iii) Findings for Test Anxiety

TAQ15- Before my Japanese language class, I feel very sure and relaxed.

TAQ14-I feel more tense and nervous in my Japanese language class than in my other classes.

TAQ13-Japanese language class moves so quickly I worry about getting left behind.

TAQ12-I don't feel pressured to prepare very well for the Japanese language class.

TAQ11-The more I study for a Japanese language test, the more confused I get.

TAQ10-I can feel my heart pounding when I'm going to be called on in the Japanese language class.

TAQ9-I often feel like not going to my Japanese language class.

TAQ8-Even if I am well prepared for the Japanese language class, I feel anxious about it

TAQ7-In Japanese language class, I can get so nervous I forget things I know.

TAQ6-I don't understand why some people get so upset over Japanese language class.

TAQ5-I worry about the consequences of failing my Japanese language class

TAQ4-I am usually at ease during my tests in the Japanese language class

TAQ3-During Japanese language class, I find myself thinking about things that have nothing to do with...

TAQ2-It wouldn't bother me at all to take more Japanese language classes

TAQ1-I tremble when I know that I'm going to be called

on in the Japanese language class.

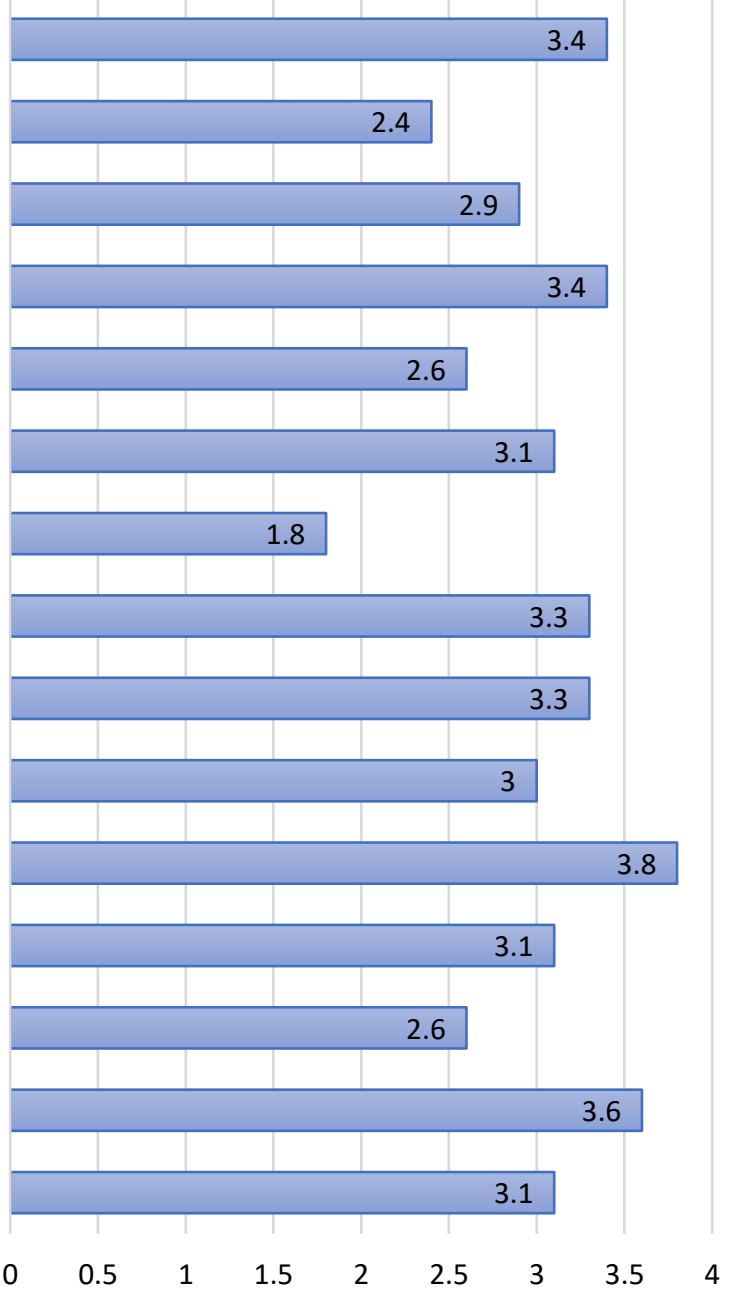

Figure 8d-mean for Test Anxiety

In figure 8d, the students are concerned about failing the test "I worry about the consequences of failing my Japanese language class" (3.8). The second highest mean score is (3.6) "It wouldn't bother me at all to take more Japanese language classes", followed by (3.4) "Before my Japanese language class, I feel very sure and relaxed", and "I don't feel pressured to prepare very well for the Japanese language class". The lowest mean score is (1.8) for "I often feel like not going to my Japanese language class". The overall results in this section indicate that the level of anxiety among the students is rather moderate. 
Findings for Positive Effect

This section presents findings for research question 4: How do positive effects influence the learning of Japanese as a foreign language?

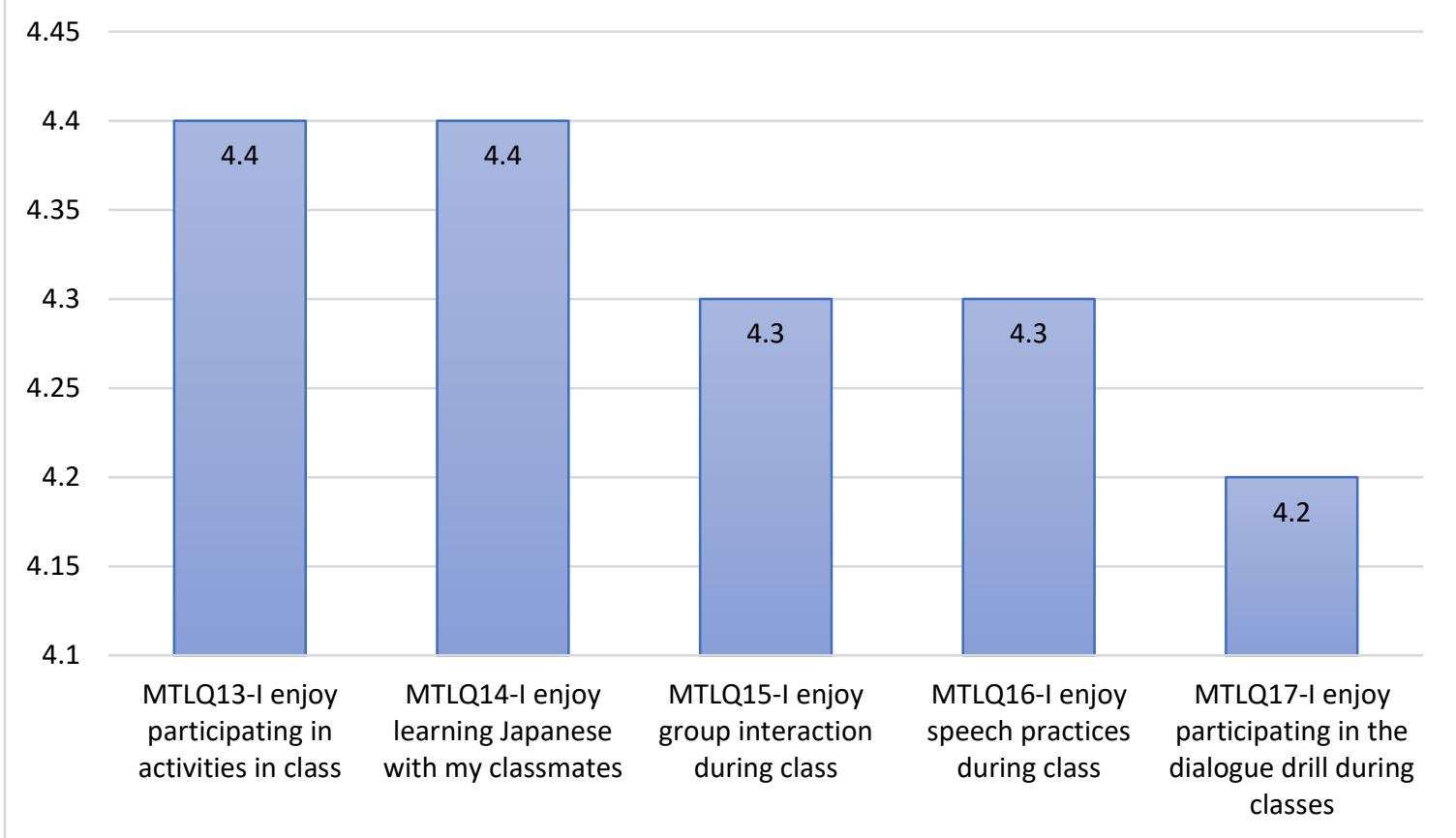

Figure 9- Mean for Positive Effect

Based on figure 9, it can be concluded that most respondents feel the joy of learning the Japanese language. This includes activities participation with their classmates (4.4) and class activities such as speech practices and dialogue (4.3 and 4.2). It can be inferred that interactive activities that have been implemented within lessons are widely enjoyed by students.

\section{Conclusion}

\section{Summary of Findings and Discussion}

Gardner's (2001) theory focuses on the second language acquisition contexts and outcomes. Many pieces of research have shown that in the process of learning a second or foreign language, negative factors could be overcome by positive factors.

In summary, this study revealed interesting findings on learners' desire to learn a foreign language. Findings showed their desire to learn is voluntary and instrumental. Next, findings also showed that foreign language learners needed social support. When it comes to fear of learning the language, they feared not understanding what was taught by the teachers. They also had low self-esteem among their peers. In addition, they feared the consequences of failing.

Students usually learn a foreign language because of their interest in the target country's culture. Awang Boon at el. (2021) mentioned that students are motivated when they recognised the importance of acquiring the language as an added value for their future, either in pursuing their studies at a higher level or in job hunting after graduation. Little do they know that they might encounter positive and negative vibes that may end them successfully or fail to help them to achieve what they hope during the learning process. 
In this study, students have shown a strong desire to learn the Japanese language. It is clearly shown that the students are interested and highly motivated in putting effort into learning the Japanese language because they know the importance of the language, and it would be helpful for their future use. However, during the process of learning, students do experience fear and anxiety. They fear not understanding the classroom instructions and the ongoing evaluations that they must take during the process of their studies. The anxiety that they are facing during tests. They lose confidence in themselves and are nervous when speaking Japanese.

The data shows that although the students faced fear and anxiety, they also made various efforts to overcome the problems. They ensure that they can understand the lesson of the Japanese language by preparing for the class beforehand. They also seek assistance from lecturers and friends, as well as go online to have a better understanding of the lesson. Although students have mixed feelings when attending the Japanese language lectures, the outcome of the lectures has a very positive effect. With activities they participated in during the lectures, students were able to overcome their fear and anxiety, and at the same time enjoyed their lessons.

The research done by Awang Boon et al. (2021) mentioned that in the process of learning a foreign language, students would face some negative factors that may cause them to withdraw from their studies. However, these negative factors may be overcome by positive factors which motivate the students. The studies by Abdullah et al. (2021) stated that students of the Japanese language felt the fear of making mistakes and fear of being unable to answer questions asked by the lecturer during the online lecture with the presence of a native speaker. However, the students were motivated to continue joining the online classes and not give up on learning the language because of the positive factors they gained from the online courses. These two pieces of research proved that positivity could overcome negativity. In another word, the fear or anxiety faced by students during foreign language learning can be overcome if they are motivated and knew their motives for learning the language.

\section{Pedagogical Implications and Suggestions for Future Research}

Almost every education system is paralysed when the pandemic hits the world. Most institutions in the world are forced to switch from physical to online learning. The new methodology may not be perfect too. Lin et al. (2017) concluded that technology tools are a suitable learning method for the young generation compared to traditional learning methods and students are more motivated. A similar study should be done but focusing on adult learners whether they too are motivated during classes when technology tools are involved. Another research was done by Chung et al. (2020) on online learning readiness among university students in Malaysia discovered that there are pros and cons to these virtual lectures. Female students are more willing to pursue online learning than male students. Undergraduate students' academic achievement is much better than that of diploma students. Researchers should do studies in this area too but on a bigger scale of respondents.

Even if the pandemic ends, the future teaching and learning methodology may merit the physical and virtual lectures as both have advantages and disadvantages. Further research on virtual learning involving learners with different genders, ages, levels of education, should be considered. The finding of the studies can be the benchmark for further improvements and the betterment of this methodology. The outcome of the studies may show a different 
impact on these respondents. Researchers should also relate the theory of motivation and fear of learning a foreign language with the new methodology.

\section{References}

Abdullah, N. A. T., Choong, P. Y., Shaharuddin, G. S., \& Abdul Rashid, N. R. (2021). Japanese Language Students' Perceptions on Online Nihongo Partner Program. International Journal of Modern Languages and Applied Linguistics, Vol 5, No. 3 (2021) pp 138-158. Available at DOI: https://doi.org/10.24191/ijmal.v5i3

Azar, A. S., \& Tanggaraju, D. (2020). Motivation in second language acquisition among learners in Malaysia. Studies in English Language and Education, 7(2), 323-333. Retrieved from: DOI: https://doi.org/10.24815/siele.v7i2.16506

Awuah, G. K. (2018). Early Career Academics' Reflections on Learning to Teach in Central Europe. Group Work as a Tool to Improve Participation and Overcome Fear of Foreign Languages Among Non-Native English Speakers (pp. 22-29). Staff and Educational Development Association.

https://www.seda.ac.uk/resources/files/Early_career_academics_reflections_on_lear ning_to_teach_entire_book.pdf

Boon, M. H. A., Abdullah, N. A. T., Rahmat, N. H., Ahmad, N., Sharif, S., \& Yean, C. P. (2021). Balancing Negative and Positive Factors in Foreign Language Learning. International Journal of Asian Social Science, 11(8), 376-387. https://doi.org/10.18488/journal.1.2021.118.376.387

Chamot, A. U. (2005). Language learning strategy instruction: Current issues and research. Annual review of applied linguistics, 25, 112-130. https://doi.org/10.1017/S0267190505000061

Chung, E., Subramaniam, G., \& Dass, L. C. (2019). Online Learning Readiness Among University Students in Malaysia Amidst Covid-19. Asian Journal of University Education (AJUE) Volume 16, Number 2, July 2020. Available at https://doi.org/10.24191/ajue.v16i2.10294

Dörnyei, Z. (2005). Motivational strategies in the language classroom. Cambridge University Press.

Dornyei, Z (1990). Conceptualizing Motivation in Foreign-Language Learning. A Journal of Research in Language Studies. Volume 40, Issue 1. 1990. Pages 45-78. Retrieved from https://doi.org/10.1111/j.1467-1770.1990.tb00954.x

Gardner, R. C. (2001). Integrative motivation and second language acquisition. In Z. Dörnyei, \& R. Schmidt (Eds.), Motivation and Second Language Acquisition (pp. 1-19). Hawaii: University of Hawaii Press.

Gardner, R., \& Lambert, W. (1972). Attitudes and motivation in second language learning. Newbury House.

Gardner, R. C. (1985). Social Psychology and Second Language Learning: The Role of Attitude and Motivation. London: Edward Arnold.

Gonzales, R. (1997). Nihongo No Benkyoo: Learning Strategies and Motivation of Filipino Learners of the Japanese Language. Layag, 3, 1:1-11.

https://www.researchgate.net/publication/299366117_Nihongo_No_Benkyoo_Learni ng_Strategies_and_Motivation_of_Filipino_Learners_of_the_Japanese_Language

Hashemi, M. (2011). Language Stress and Anxiety Among The English Language Learners. Procedia - Social and Behavioral Sciences, 30, 1811-1816.

https://doi.org/10.1016/j.sbspro.2011.10.349 
Horwitz, E. K. (1986). Preliminary evidence for the reliability and validity of a Foreign Language Anxiety Scale. TESOL Quarterly, 20 (3), 559- 562.

https://doi.org/10.2307/3586302

Horwitz, E. K., Horwitz, M. B., \& Cope J. A. (1986). Foreign language classroom anxiety. Modern Language Journal, 70, 125-132. http://dx.doi.org/10.1111/j.15404781.1986.tb05256.x

Ijuin, M., \& Wydell, T. N. (2018). A Reading Model from the Perspective of Japanese Orthography: Connectionist Approach to the Hypothesis of Granularity and Transparency. Journal of Learning Disabilities, 51(5), 490-498. https://doi.org/10.1177/0022219417718200

Lin, H. C. K., Chao, C. J., \& Huang, T. C. (2015). From a Perspective on Foreign Language Learning Anxiety to Develop an Effective Tutoring System. Educational Technology Research and Development, October 2015, Vol. 63, No. 5, 727-747. https://www.jstor.org/stable/24546647

Lin, M. H., Chen, H. C., \& Liu, K. S. (2017). A Study of the Effects of Digital Learning on Learning Motivation and Learning Outcome. EURASIA Journal of Mathematics Science and Technology Education, 2017 13(7):3553-3564. Available at DOI: 10.12973/eurasia.2017.00744a

Mardani, D. (2019). Learning Japanese Language Based on 2013 Curriculum at Elementary Schools in Bali. Advances in Social Science, Education and Humanities Research, volume 394 3rd International Conference on Innovative Research Across Disciplines (ICIRAD 2019). Retrieved from: file:///C:/Users/60122/Downloads/125932495.pdf

Nuibe, Y., Kano, F., \& Ito, K. (1995). International survey on university student motivation In case of Victoria University in New Zealand . Journal of Japanese-Language

Education, 86, 162-172. http://id.ndl.go.jp/bib/000000018416 Oxford, R. L. (1990). Language learning strategies: What every teacher should know. Boston, MA: Heinle and Heinle Publishers

Purwaningrum, E. W., Hamamah, \& Degeng, P. D. D. (2020). Japanese Language Learners Anxiety: Barriers or Successful Support. Jurnal Budaya FIB UB, 1(1),pp 1-9. https://jurnalbudaya.ub.ac.id/index.php/jbb

Rahmat, N. H. (2020). Investigating The Cycle of Fear in Foreign Language Learning. European Journal of Foreign Language Teaching, 5(1). Pp 117-127. https://doi.org/10.46827/ejfl.v5i1.3245

Ramírez, N. O. (2014) The Influence of Motivation in Foreign Language Learning Process. Fórum De Recerca, No 19/2014. Pp 695-707. ISSN 1139-5486. Available at http://dx.doi.org/10.6035/ForumRecerca.2014.19.44

Rethinasamy S., Paee R., \& Ramanair J. (2021). Malaysian Undergraduates' Beliefs and Motivation for Learning Japanese as a Foreign Language. Turkish Online Journal of Qualitative Inquiry. Vol.12. No.6. Retrieved from https://www.tojqi.net/index.php/journal/article/view/1394

Santiar, L., Emzir, E., Rasyid, Y. (2018). Reading Strategies to Overcome Difficulties in Understanding Japanese Sentences. Advances in Social Science, Education and Humanities Research, volume 254. Retrieved from file://C:/Users/60122/Downloads/125911454.pdf

Supida, I. N., Aryati, K. F., Susanta, I. P. A., \& Anggayana, I. W. A. (2020). The Development of Syllabus and Lesson Plan Based on English for Occupational Purposes. International 
Journal of Psychosocial Rehabilitation, Vol. 24, Issue 4 (2020). Available at https://doi.org/10.37200/IJPR/V24I4/PR201009

Taguchi, T., Magid, M., and Papi, M. (2009). The L2 motivational self system among Japanese,Chinese, and Iranian learners of English: A comparative study. In Z. Dörnyei \& E. Ushioda (Eds.), Motivation, language identity and the L2 Self, (pp. 66-97). Clevedon: Channel View Publications. Retrieved from https://doi.org/10.21832/9781847691293-005

Tamada, Y. (1996). Japanese Learners' Language Learning Strategies: The Relationship between Learners' Personal Factors and Their Choices of Language Learning Strategies. Lancaster University. Unpublished Masters Thesis. Retrieved from https://files.eric.ed.gov/fulltext/ED401746.pdf

The Japan Foundation. (2018). Survey on Japanese Language Education Abroad. Tokyo, Japan. Retrieved from https://www.jpf.go.jp/e/project/japanese/survey/result/survey18.html The Japan Foundation 2019-2020 Annual Report. Retrieved from: https://www.jpf.go.jp/e/about/result/ar/2019/pdf/dl/ar2019e.pdf

Vetrinskaya, V. V., Poliakova, N. V., Shabanova, V. P. (2020). The Use of Video Materials for the Development of Inner Motivation in Learning Foreign Languages of University Students. Universal Journal of Educational Research 8(12): 7101-7108, 2020. DOI: $10.13189 /$ ujer.2020.081277

Yashima, T., Nishida, R., Mizumoto, A. (2017). Influence of Learner Beliefs and Gender on the Motivating Power of L2 Selves. Volume101, Issue4. Pages 691-711.

Retrieved from: https://onlinelibrary.wiley.com/doi/abs/10.1111/modl.12430

Zakaria, N. L., Abd Aziz, A., \& Ramayah, K. (2017). Language learning strategies and learner autonomy in learning Japanese. Journal of Advanced Research in Social and Behavioural Sciences, 9(3), 50-60.

https://www.akademiabaru.com/doc/ARSBSV9_N3_P50_60.pdf 